Lukas Kakalejcik,

Ph.D., GrowthPro s. r. o., Slovakia

email: kakalejcik.lukas@gmail.com

Richard Fedorko,

Ph.D., Associate Professor, The University of Presov in Presov, Slovakia

DORCID ID, 0000-0003-3520-1921

email: richard.fedorko@unipo.sk

Beata Gavurova,

Ph.D., Professor, Technical University of Kosice, Slovakia

DORCID ID, 0000-0002-0606-879X

email: beata.gavurova@tuke.sk

Radovan Bacik,

Ph.D., Associate Professor, The University of Presov in Presov, Slovakia

DORCID ID, 0000-0002-5780-3838

email: radovan.bacik@unipo.sk

Correspondence author: beata.gavurova@tuke.sk

\title{
CAN NEGATIVE WORD-OF-MOUTH HAVE ANY IMPACT ON BRAND SUSTAINABILITY?
}

Abstract. Companies invest large amounts of funds to support their image as an incentive to make customers purchase the company's products. This paper's main objective is to estimate the impact of negative word-of-mouth on brand/product sustainability. As word-of-mouth represents customers' conversation regarding the quality of the company's products, the customer's voice is often analyzed to avoid negative experience outreach. History has carried several cases in which outreach could endanger a company's bottom line or even existence. The purpose of our study was to find out if this assumption could be supported. Approximately 100000 product reviews were collected in six selected categories in the Slovak market. The quantity of positive and negative word-of-mouth (PWOM/NWOM) was analyzed. It was found that there are approximately 15 times more positive reviews than negative ones. Based on previous studies' results, worst- and best-case scenarios were modeled to determine the possible impact of both PWOM and NWOM. It was found that in both cases, the direct reach of PWOM is higher than that of NWOM. On average, in the worst-case scenario, the reach of PWOM is 3.93 times higher than the reach of NWOM. In the best-case scenario, the reach of PWOM is 8.85 times higher than the reach of NWOM. According to the results, brand managers should focus on getting more positive reviews and thus positive word-ofmouth as it may have a stronger effect on the brand's sustainability. In other words, getting more ambassadors from the pool of customers satisfied with the brand might seem a reasonable strategy to avoid the potential danger from customers who were not satisfied with the products and willing to spread the word about their dissatisfaction.

Keywords: word-of-mouth, brand perception, brand management, brand reputation.

Introduction. For decades, marketing professionals have been trying to convince their customers to spread the word about their products or brands to other people. Information and communications technologies have enabled the rise of peer-to-peer-based activity of obtaining, giving, or sharing access to goods and services, coordinated through online services (Hamari et al., 2016). Nowadays, customers interact with firms through myriad touchpoints in multiple channels and media. Understanding customer experience and the customer journey over time is critical for firms (Ferencakova et al., 2020; Lemon and

Cite as: Kakalejcik, L., Fedorko, R., Gavurova, B., \& Bacik, R. (2021). Can Negative Word-of-Mouth Have Any Impact on Brand Sustainability?. Marketing and Management of Innovations, 1, 212-224.

212 http://doi.org/10.21272/mmi.2021.1-16 
Verhoef, 2016). Positive consumer behavior is one of the cornerstones of long-term business success (Malar et al., 2011; Kumar et al., 2016; Prayag et al., 2017; Stefko et al., 2014; Victor et al., 2018), whose key source is the good reputation of the company (Kim and Park, 2013; Book et al., 2018; Markovic et al., 2018; Pencarelli et al., 2018). Balmer and Greyser (2003) defined the company's reputation as a state formed over a longer period based on what the company does and how it is maintained. However, could bad reviews of the customers impact the company's reputation or even jeopardize its sales or lifespan? The purpose of this study is to come out with a plausible approximation to support or question these assumptions.

Literature Review. Companies usually invest large amounts of funds to support marketing activities to support the company's image as an incentive to customers to making a purchase (Mura, 2020; Miklosik et al., 2020; Fedorko and Kakalejcik, 2015; Leboff, 2011; Keh et al., 2006). Smaizien and Jucevicius (2009) argue that companies choose to spotlight the image and omit their reputation. A good image is no guarantee of positive references and recommendations. These could be accomplished through a positive reputation (Yağmur and Aksu, 2020; Leboff, 2011). While being extremely important in online markets of e-business, reputation could influence less informed customers via successful seller quality signals (Bakos and Dellarocas, 2011; Bertarelli, 2015; Weberova et al., 2016; Badawi et al., 2017).

These incentives have eventually resulted in the discipline called word-of-mouth (WOM) marketing. Managers are very interested in WOM communication because they believe that a product's success is related to the WOM that it generates (Godes and Mayzlin, 2004).

There are two goals of WOM marketing: 1) to give people reason to talk about products and brands; and 2) to make it easier for this conversation to take place (Sernovitz, 2015). Some authors, such as Romaniuk and Sharp (2016), cut the term's pomposity, claiming that WOM is just a regular conversation among customers. Apart from the terminology, it is true that customers seek advice before the purchase of a product. The studies listed further in this paper also show that WOM could impact customers' willingness to purchase a product. It should be emphasized that the Internet and technological development in this field offers many opportunities for value creation and promotion, but it also presents important challenges (Fortezza and Pencarelli, 2015; Bigosińska, 2015).

Moreover, with the continually expanding online environment, a customer could easily find information about other customers' experience in minutes via social media (Bertan, 2020), product comparison websites, review sites, or e-commerce stores (e.g., Amazon) usually contain genuine product reviews. Forman et al. (2008) suggest that consumer-generated product reviews are driven by the notion of consumers' decisions about purchasing or not purchasing a product. It is based on the positive or negative information about that product obtained from fellow consumers. Product reviews supplement other information provided by electronic storefronts, such as product descriptions, reviews from experts, and personalized advice generated by automated recommendation systems (Mudambi and Schuff, 2010). These online reviews have become an important source of information to enable consumers to seek accurate and honest information by sharing their own experiences (Thakur, 2018; Gretzel and Yoo, 2008). Lackermair et al. (2013) consider consumer-generated reviews to be very popular marketing tools to support consumers' purchasing decisions. The credibility of these reviews is also an important issue. Businesses that commit fraud scams could create false reviews for themselves or their competitors (Luca and Zervas, 2016). Generally, negative reviews could quickly and severely damage the company's image and reputation (Siano et al., 2011). Based on various studies (Basuroy et al., 2003; Cao et al., 2011; Chevalier and Mayzlin, 2006). Yin et al. (2016) stated that negative ratings might hurt sales more than positive ratings help sales in diverse product categories. An explanation for this negative effect is that from an evolutionary standpoint. Humans are more alert to risks in the environment because such risks have been more critical to our survival (Yin et al., 2016; Vaish et al., 
2008). Therefore, to mitigate these risks, different forms of social dialogue were developed in the living and working environment (Bilan et al., 2020a). Moreover, the percentage of negative reviews has a greater effect (on new product sales) than that of positive reviews, confirming the negativity bias (Cui et al., 2012). Credible and representative reviews could be achieved by implementing appropriate design and policy in online review systems (Askalidis et al., 2017). The availability of customer feedback has resulted in a separate term called online WOM, which stands for «any positive or negative statement made by potential, actual or former customers about a product or company, which is available to a multitude of people and institutions via the Internet» (Hennig-Thurau et al., 2003). Wetzer et al. (2007) suggest that the main factor driving negative WOM is the desire to warn others and strengthen social bonds.

Word-of-mouth is a direct result of the customer's experience of extracting the utility (or lack of it) from products (in this case, products to be either goods or services were considered). Based on Li and Hitt (2008), this customer experience could be influenced by adjusting marketing strategies such as pricing, advertising, or product design. In some cases, positive WOM could be caused by nostalgic attitudes towards brands, for instance, known from childhood (Grębosz-Krawczyk, 2019) and developed by a strong experience of trust for the brand (Kim and Chao, 2019). Negative feedback itself, if appropriately communicated, is a means of creating a positive WOM (Proserpio and Zervas, 2017; Brunner et al., 2019).

Several studies have tried to examine how the experience affects the sentiment of WOM. The White House Office of Consumer Affairs (Shaw, 2018) found out that dissatisfied customers will talk to nine to 15 people about their experiences. Around $13 \%$ of dissatisfied customers share their experiences with more than 20 people. On the other hand, happy customers who get their issue resolved to talk to four to six other people about their experiences. Robbins (2018) claims that $79 \%$ of customers talk about their negative experiences.

On the other hand, only $72 \%$ of customers share their positive experiences. However, this study found that most satisfied and dissatisfied customers share their experiences with one to five other people. That significantly contradicts the study written by the White House Office of Consumer Affairs (Shaw, 2018). The study by Schijns and van Bruggen (2018) came out with the result that in the case of electronic WOM, negative WOM has a greater negative impact on trust and behavioral loyalty. However, there was not any significant effect on attitudinal loyalty and satisfaction. De Matos and Rossi (2008) observed that satisfaction has a stronger relationship with positive WOM than loyalty, whereas (dis)loyalty has a stronger relationship with negative WOM than does (dis)satisfaction.

Lee et al. (2016) found out that consumers conform to online consumer reviews, and their attitudes towards the purchased product become unfavorable as the proportion of negative online consumer reviews increases. In other words, the increasing ratio of negative WOM and total WOM makes customers more certain that the product would not meet their expectations.

In turn, Martin (2017) found that negative WOM diminishes the customer attitude towards the product, while positive WOM happens to have a much higher level of stronger and positive effect on their attitude towards the product. The results suggest that positive WOM has a much greater impact than negative WOM. Sweeney et al. (2014) obtained similar results. When discussing brand equity, the authors claimed that brand equity perceptions enhance the message's influence when there is a positive WOM message. Still, it reduces this influence when the WOM message is negative. The study by East et al. (2016) provides evidence that positive WOM usually has more effect on the purchase intention than negative WOM. Similar findings were obtained for employer brand and main tools of employees' satisfaction with work ensuring (Bilan et al., 2020b; Mičík and Mičudová, 2018).

Chevalier and Mayzlin (2006) stated that the impact on sales of one-star reviews (negative WOM) is greater than the impact of five-star reviews (positive WOM) and customers read review text rather than 
relying only on summary statistics. Vázquez-Casielles et al. (2013) examined the relative impacts of positive and negative WOM on the shift in the receiver's brand purchase. The empirical analysis has shown that positive/negative WOM has a positive/negative impact on the receiver's brand-purchase probability shift. The results also show that positive WOM has a stronger impact on the brand purchase probability than negative WOM. Berger et al. (2010) also suggest that negative publicity could increase purchase likelihood and sales by increasing product awareness.

The study by East et al. (2007) showcases the penetration of positive (PWOM) and negative (NWOM) conditional word-of-mouth in the UK (and also in the US in the case of the credit card and the holiday destination industry). The authors claim that there is approximately 3.7 times more positive WOM than negative WOM. Figure 1 demonstrates the results from the same research question type («If asked about $X$, would you recommend ...?» and «If asked about X, would you advise against ...?»). It is possible to spot that although the credit card and holiday destination industry receives significantly more positive than negative WOM, the restaurant and bank sectors' situation is more strained.

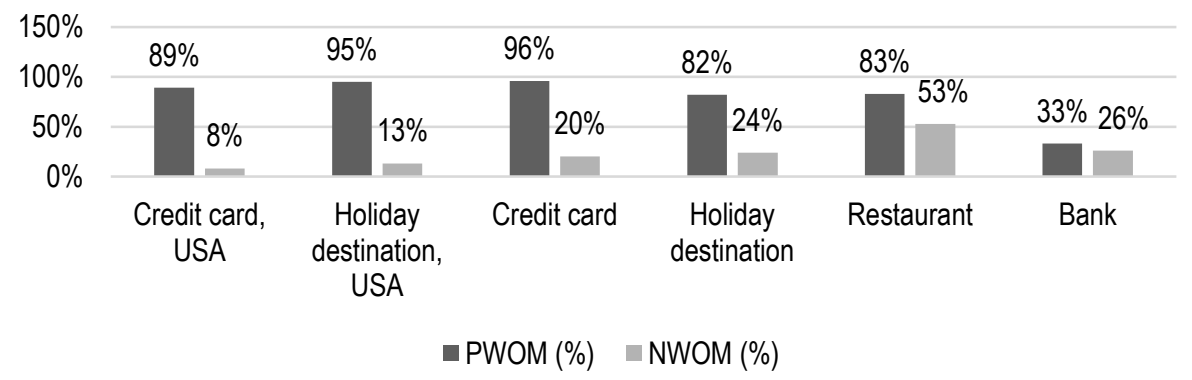

Figure 1. Penetration of positive (PWOM) and negative (NWOM) word-of-mouth Sources: developed by the authors.

To summarize the review, the first set of studies pointed out that the customer's negative experience (and therefore negative WOM) may be dangerous for the brand because it could harm the brand image and decrease sales. The marketing industry and educational institutions support and disseminate this idea for years. Kotler et al. (2017) have embraced this idea in several editions of their book, which is often listed in bibliographies of marketing textbooks. However, the second set of studies has shown that negative WOM's effect is lower than positive. Moreover, East et al. (2007) showed that there was more positive than negative WOM. This triple-sided contradiction helps to use arguments found in these studies and apply them to the selected product categories to determine the impact of negative WOM in the Slovak market.

Methodology and Research Methods. This paper's main objective is to estimate the impact of negative word-of-mouth (NWOM) on the customer's the brand/product perception. The main objective could be broken down into the following:

1. Analyze the current knowledge regarding the impact on positive and negative word-of-mouth (PWOM/NWOM).

2. Analyze the sentiment (positive or negative) based on the selected product categories (mobile devices, car accessories, cosmetics, movies, books and games, hotels, and restaurants).

3. Estimate the impact of NWOM and PWOM based on the findings found in 1 and 2.

The first step of the analysis was to identify online portals focusing on customer feedback in the B2C e-commerce segment to achieve the objective. The decisive factor in this selection was the completeness of data for subsequent analysis (absolute values). The selection of suitable portals was 
also influenced by their local popularity, namely the number of active e-commerce subjects and the technical capability for automated data collection. Based on the selection criteria, this study managed to identify two online portals. The main reason for not choosing other portals was the inconsistency of the portals' rated variables, the insufficient number of rated entities, and the technical incapacity for automatic data collection.

The first identified portal was Heureka.sk. It is the biggest price comparator and a shopping portal on Slovak online market. It is visited each month by an average of one and a half million real users, who choose from seven million products and thousands of online stores. The portal is among the 10 most visited sites in the Slovak Republic. This portal allowed receiving ratings in mobile devices, car accessories, cosmetics, movies, books, and games. In addition to the product mentioned above categories, customer reviews of one of the largest e-commerce entities in the B2C segment of the Slovak Internet market within the Heureka.sk portal were engaged. Specifically, it is the Mall.sk e-shop, which has a wide range of product categories. Revenues from this e-shop reached EUR 60.5 million in 2017.

The second best portal for the study's purposes was TripAdvisor.com. It is the largest travel community in the world. The website is visited by almost 456 million unique visitors per month. It contains over 661 million reviews covering over seven million accommodations, restaurants, and tourist attractions. The website offers opinions from other travelers, tools for travel planning, and direct links to booking tools that could search through hundreds of websites and find the best hotel prices. TripAdvisor operates its website in 49 markets around the globe (Trip Advisor Media Centre). The website allows users to add reviews, book accommodation directly, or use analytical tools to monitor selected variables focusing on customer satisfaction, engagement, competition, and selected geographic areas.

Data collection was provided using automatic data collection by using a script in the programming language PHP 5.6.30, MySQL 5.7.18 databases, phpMyAdmin 4.7.0 MySQL database manager, and the Apache 2.4.26 webserver. With the help of the above mentioned technologies, a script has been created to identify the source code's role on the rated entities' sub-pages and record the selected variables within the database. For the analysis, the following identified variables were selected within the Heureka.sk portal at the customer rating level: unique ID rating, date and time of the added rating, trade referral rate expressed as a percentage. For TripAdvisor.com, the following identified variables were unique: unique ID rating, date of the added rating, and customer rating on a scale of 1-5 (where 5 is the best rating). The collection of data took place in July and August 2018. For Heureka.sk, a total of 1,653 profiles of e-commerce entities were identified. Subsequently, this study was focused on the product categories mentioned above. As part of this step, 34,703 unique customer ratings were identified and collected. Table 1 presents the number of customer ratings for each product category. The total number of unique customer ratings for Mall.sk e-shop (via Heureka.sk) was 39,995. Customers created the ratings described above from 19 March 2015 to 15 July 2018.

In the case of TripAdvisor.com, a total of 271 hotel profiles and 1,257 restaurant profiles were identified. The identified hotel and restaurant profiles contained at least 10 customer reviews. Customers created the above-described ratings from 9 May 2004 to 18 August 2018.

Table 1. Summary of the collected data

\begin{tabular}{lcc}
\hline \multicolumn{1}{c}{ Source } & Category & Number of Ratings \\
\hline Mall.sk (via. Heureka.sk) & General & 39.995 \\
Heureka.sk & Mobile devices & 4.808 \\
Heureka.sk & Car accessories & 9.152 \\
Heureka.sk & Cosmetics & 19.183 \\
Heureka.sk & Movies, books, and games & 1.560 \\
\hline
\end{tabular}


L., Kakalejcik, R., Fedorko, B., Gavurova, R., Bacik. Can Negative Word-of-Mouth Have Any Impact on Brand Sustainability?

\begin{tabular}{lcc}
\hline & & \\
& & Continued Table 1 \\
\hline TripAdvisor & Hotels & $\mathbf{5 . 4 7 5}$ \\
TripAdvisor & Restaurants & 19.631 \\
\hline
\end{tabular}

Sources: developed by the authors.

Results and Discussion. As mentioned in the previous section, the study was managed to gather approximately 100,000 reviews from several product categories. It allowed examining the occurrence of positive and negative word-of-mouth in the Slovak market. Table 2 showcases the distribution of ratings based on the proportional evaluation of products by customers. As TripAdvisor reviews were on a different scale (1-5) compared to Mall.sk and Heureka.sk (0-100\%), we decided to divide the rating into five breaks to unify the data scale. When it comes to the rating behavior, more reviews are representing unambiguous ratings $(0-20 \%$ and $81-100 \%$ more precisely) than reviews representing ambiguous, more undecided ratings (21-40\% and $81-100 \%$ more precisely).

Moreover, there are more neutral reviews (41-60\%) than ambiguous negative reviews (21-40\%) in all the monitored categories. It may mean that people rate a product as neutral instead of negative. Within all categories, there are also more ambiguous positive reviews than neutral ones. That may mean that customers tend to evaluate the product rather slightly positively than in a neutral manner in case of neutral feelings.

Table 2. Distribution of ratings across categories

\begin{tabular}{lccccc}
\hline \multirow{2}{*}{ Category } & \multicolumn{5}{c}{ Rating } \\
\cline { 2 - 6 } & $\mathbf{0 - 2 0 \%}$ & $\mathbf{2 1 - 4 0 \%}$ & $\mathbf{4 1 - 6 0 \%}$ & $\mathbf{6 1 - 8 0 \%}$ & $\mathbf{8 1 - 1 0 0 \%}$ \\
\hline General & 2.925 & 1.176 & 2.088 & 5.021 & 27.017 \\
Car accessories & 244 & 78 & 281 & 973 & 7.576 \\
Movies, books, and games & 37 & 18 & 64 & 146 & 1.301 \\
Cosmetics & 461 & 201 & 715 & 1.681 & 16.125 \\
Mobile devices & 384 & 120 & 213 & 529 & 3.562 \\
Restaurants & 1.488 & 1.166 & 2.156 & 4.233 & 10.588 \\
Hotels & 289 & 335 & 823 & 1.336 & 2.692 \\
\hline
\end{tabular}

Sources: developed by the authors.

The label «NWOM» was put to the first two breaks' values $(0-20 \%, 21-40$ Besides, the values in the fourth and fifth breaks ( $61-80 \%, 81-100 \%)$ were labeled as «PWOM». The middle break (41-60\% in case of Mall.sk and Heureka.sk and three in case of TripAdvisor) was removed because this evaluation was rather neutral than positive/negative. Table 3 shows significantly more positive word-ofmouth than negative word-of-mouth (on average, there is 15.39 times more PWOM than NWOM). When it comes to the category labeled as General, it is possible to see 7.81 times more PWOM than NWOM. As this label represents all the categories available at Heureka.sk and is backed by almost 40,000 reviews, we consider this value to be the average proportion of PWOM and NWOM when purchasing goods. However, some product categories (car accessories, movies, books and games, cosmetics) do not suffer from negative word-of-mouth because the total occurrence of negative word-of-mouth in these categories is approximately $3.50 \%$. When it comes to Mobile devices, the occurrence of NWOM is slightly lower than in the category labeled as General. There is more NWOM in the Restaurant and Hotels category. However, compared to the study (East et al., 2016), there is less negative word-ofmouth. There might be more NWOM in the categories of Restaurants, Hotels, and Mobile devices than the rest of the monitored categories because of the nature of the products. As humans need to consume food, hotels become their second home for a period. Mobile devices have become an integral part of 
L., Kakalejcik, R., Fedorko, B., Gavurova, R., Bacik. Can Negative Word-of-Mouth Have Any Impact on Brand Sustainability?

daily life. So, people might be more sensitive when it comes to issues connected to these two categories. Thus, the businesses obtained higher rates of NWOM.

Table 3. Occurrence of positive (PWOM) and negative (NWOM) word-of-mouth across categories

\begin{tabular}{|c|c|c|c|c|c|c|}
\hline Category & PWOM & NWOM & $\begin{array}{l}\text { Proportion of } \\
\text { PWOM/NWOM }\end{array}$ & PWOM (\%) & NWOM (\%) & $\mathbf{N}$ \\
\hline General & 32.038 & 4.101 & 7.81 & 83.81 & 10.73 & 38.227 \\
\hline $\begin{array}{l}\text { Car } \\
\text { accessories }\end{array}$ & 8.549 & 322 & 26.55 & 93.41 & 3.52 & 9.152 \\
\hline $\begin{array}{l}\text { Movies, books, } \\
\text { and games }\end{array}$ & 1.447 & 55 & 26.31 & 92.40 & 3.51 & 1.566 \\
\hline Cosmetics & 17.806 & 662 & 26.90 & 92.82 & 3.45 & 19.183 \\
\hline Mobile devices & 4.091 & 504 & 8.12 & 85.09 & 10.48 & 4.808 \\
\hline Restaurants & 14.821 & 2.654 & 5.58 & 75.50 & 13.52 & 19.631 \\
\hline Hotels & 4.028 & 624 & 6.46 & 73.57 & 11.40 & 5.475 \\
\hline Average & $x$ & $X$ & 15.39 & 85.23 & 8.09 & $x$ \\
\hline
\end{tabular}

Sources: developed by the authors.

There were some cases in which companies got hurt by negative word-of-mouth by unsatisfied customers. The goal was to determine the hypothetical impact of PWOM and NWOM based on their respective occurrences. Besides, the study aimed to get the findings from previous studies that had examined the word-of-mouth impact. To determine this impact, the White House Office of Consumer Affairs findings (Shaw, 2018) was used to create two hypothetical scenarios relating to the direct reach of both PWOM and NWOM. The worst-case scenario worked with the assumption that $13 \%$ of customers talk about their negative experiences to 20 or more people (this assumption was used in both worst-case and the best-case scenarios as it was difficult to set the upper boundary for the worst-case scenario). In contrast, the rest of the unsatisfied customers talk to 15 other people about their experiences. In the worst-case scenario, we set the rule under which satisfied customers will talk to four other people about their experiences. For the best-case scenario, the rule was set under which $13 \%$ of customers talk to 20 other people about their negative experiences. In turn, the rest of the unsatisfied customers talk to nine other people, and customers with positive experiences talk to six other people. Table 4 displays the direct reach resulting in the worst-case scenario. In the worst-case scenario, there is 3.93 times more positive reach than the negative one. In the case of Car accessories, Movies, Books and games, and Cosmetics, the hypothetical reach of PWOM is almost seven times higher than in the case of NWOM. The threat by NWOM-especially in the categories Restaurants and Hotels- the reach of PWOM happens only to be 1.43 times ( 1.65 times respectively) higher than that of NWOM.

Table 4. Hypothetical direct reach: Worst-case scenario

\begin{tabular}{|c|c|c|c|c|c|}
\hline Category & $\begin{array}{c}\text { Negative }(13 \% \\
\text { talk to } 20 \text { or } \\
\text { more) }\end{array}$ & $\begin{array}{l}\text { Negative }(87 \% \\
\text { talk to } 15 \\
\text { people) }\end{array}$ & $\begin{array}{l}\text { Total negative } \\
\text { reach }\end{array}$ & $\begin{array}{c}\text { Positive } \\
\text { (100\% talk to } \\
\text { four people) }\end{array}$ & $\begin{array}{c}\text { Proportion of } \\
\text { PWOM/NWOM }\end{array}$ \\
\hline General & 10.663 & 53.518 & 64.181 & 128.152 & 2.00 \\
\hline $\begin{array}{l}\text { Car } \\
\text { accessories }\end{array}$ & 837 & 4.202 & 5.039 & 34.196 & 6.79 \\
\hline $\begin{array}{l}\text { Movies, books, } \\
\text { and games }\end{array}$ & 143 & 718 & 861 & 5.788 & 6.72 \\
\hline Cosmetics & 1.721 & 8.639 & 10.360 & 71.224 & 6.87 \\
\hline Mobile devices & 1.310 & 6.577 & 7.888 & 16.364 & 2.07 \\
\hline Restaurants & 6.900 & 34.635 & 41.535 & 59.284 & 1.43 \\
\hline
\end{tabular}


L., Kakalejcik, R., Fedorko, B., Gavurova, R., Bacik. Can Negative Word-of-Mouth Have Any Impact on Brand Sustainability?

\begin{tabular}{lccccc} 
& & & & Continued Table 4 \\
\hline Hotels & 1.622 & 8.143 & 9.766 & 16.112 & 1.65 \\
\hline Average & $\mathrm{X}$ & $\mathrm{X}$ & $\mathrm{X}$ & $\mathrm{X}$ & 3.93 \\
\hline
\end{tabular}

Sources: developed by the authors.

Table 5 presents the best-case scenario. On average, the reach of positive WOM is 8.85 times higher than the reach of WOM. In the categories Car accessories, Movies, books and games, and Cosmetics, the hypothetical reach of PWOM is more than 15 times higher than that of NWOM. Even in the case of Restaurants and Hotels, the reach of PWOM is more than three times higher than that of NWOM.

Table 5. Hypothetical direct reach: Best-case scenario

\begin{tabular}{lccccc}
\hline \multicolumn{1}{c}{ Category } & $\begin{array}{c}\text { Negative } \\
(13 \% \text { talk to } \\
20 \text { or more })\end{array}$ & $\begin{array}{c}\text { Negative }(87 \% \\
\text { talk to nine } \\
\text { people })\end{array}$ & $\begin{array}{c}\text { Total negative } \\
\text { reach }\end{array}$ & $\begin{array}{c}\text { Positive } \\
(100 \% \text { talk to six } \\
\text { people })\end{array}$ & $\begin{array}{c}\text { Proportion of } \\
\text { PWOM/NWOM }\end{array}$ \\
\hline $\begin{array}{l}\text { General } \\
\text { Car }\end{array}$ & 10.663 & 32.111 & 42.773 & 192.228 & 4.49 \\
$\begin{array}{l}\text { accessories } \\
\text { Movies, }\end{array}$ & 837 & 2.521 & 3.358 & 51.294 & 15.27 \\
books, and & 143 & 431 & 574 & 8.682 & 15.13 \\
games & & & & & \\
Cosmetics & 1.721 & 5.183 & 6.905 & 106.836 & 15.47 \\
Mobile & 1.310 & 3.946 & 5.257 & 24.546 & 4.67 \\
devices & 6.900 & 20.781 & 27.681 & 88.926 & 3.21 \\
$\begin{array}{l}\text { Restaurants } \\
\text { Hotels }\end{array}$ & 1.622 & 4.886 & 6.508 & 24.168 & 3.71 \\
Average & $\mathrm{X}$ & $\mathrm{X}$ & $\mathrm{X}$ & $\mathrm{X}$ & 8.85 \\
\hline
\end{tabular}

Sources: developed by the authors.

Based on the hypothetical direct reach results, the findings showed that negative word-of-mouth might be harmful. However, there is a significantly higher level of positive word-of-mouth reach. Based on the studies by Martin (2017), Sweeney et al. (2014), East et al. (2016), and Casielles et al. (2013) proved that positive word-of-mouth has a stronger effect on the customer's willingness to purchase a product, the negative word-of-mouth might be harmful to companies only on rare occasions. As mentioned in the results, there is also a small ratio of negative to positive reviews occurrence. Therefore, based on (Lee et al., 2008), negative word-of-mouth should not decrease customers' trust towards products.

In general, this study has filled the gap in the stream of authors who claimed that positive word-ofmouth is more important and impactful than a negative one. Thus, companies should focus more on getting positive reviews than avoiding the negative ones as 1 ) the increasing ratio of PWON/NWOM does not hurt sales (Lee et al., 2008) and 2) a higher amount of positive reviews increases the direct reach of positive word-of-mouth. These findings correspond to those in studies (Martin, 2017; Sweeney et al., 2014; East et al., 2016; Casielles et al., 2013; Lee et al., 2008). On the other hand, the study contradicts the results obtained in studies by Siano et al. (2011), Basuroy et al. (2003), Cao et al. (2011), Chevalier and Mayzlin (2006), Yin et al. (2016), and Vaish et al. (2008), as it indicated that NWOM might not have the significant impact on company's reputation and therefore on sales.

Conclusions. The idea that negative word-of-mouth may hurt a brand and company's reputation (and therefore its sustainability) among current and potential customers has been in marketing textbooks for a while. That is considered to be a general truth. This paper's main objective was to estimate the 
impact of negative word-of-mouth on brand/product sustainability. The literature review showed a contradiction among authors regarding positive and negative word-of-mouth impact on customers' brand perception. Brand perception could affect the sustainability of the business. We collected approximately 100,000 product reviews in six selected categories in the Slovak market and analyzed the quantity of positive and negative word-of-mouth. The obtained results showed that there were approximately 15 times more positive reviews than negative ones. Restaurants and Hotels as a category appeared as the most vulnerable. However, there were found 5.5 times (more precisely 6.5 times) more positive reviews than negative ones.

After examining PWOM and NWOM distribution, the goal was to determine the hypothetical direct reach of PWOM and NWOM and determine their impact on brand sustainability. This study provides modeling the worst- and the best-case scenarios based on the results of previous studies. The findings showed that in both cases, the direct reach of PWOM was higher than NWOM (however, the worst-case scenario may hurt brands in the category Restaurants and Hotels). On average, the reach of PWOM is 3.93 times higher than that of NWOM in the worst-case scenario. In turn, in the best-case scenario, the reach of PWOM is 8.85 times higher than the reach of NWOM. According to the study results, brand managers should focus on getting more positive reviews and thus positive word-of-mouth as it may have a stronger effect on brand sustainability. Brand managers could use the results to set/adjust their brand strategies. The study's methodology aimed to get as close as possible to model customer behavior's real approximation when sharing feedback regarding consumer's experience with products. However, there are several limitations without consideration during calculation of the impact of negative and positive word-of-mouth:

1. The viral effect defined by Scott (2015) wasn't considered. Viral effect higher than 1 causes one person to talk about his/her experience to more than one person. In this case, both PWOM and NWOM may spread like a virus (a basic viral marketing principle). Several cases, such as Pepsi, United Airlines, Dove, McDonald's, and Uber, among others, showed that social media helped spread NWOM globally. As this may happen in some cases with reviews used within the study, it was considered to be a limitation that could not be measured.

2. The data from hypothetical reach provided the information that any negative and positive experience is shared strictly by a set number of people. However, some people spread words about their positive/negative experiences more than others. Thus, the calculation may not be accurate. However, the results of the existing study were used to make the estimation as accurate as possible. Moreover, the rules in worst- and best-case scenarios were selected based on the study from different markets. Therefore the behavior of Slovak customers may be different in the case of experience-sharing.

3. It was monitored the reviews for the whole product category and not for particular products. There may be some better products and also worse ones. That may affect the results as better products are likely to obtain a higher ratio of PWOM/NWOM. In this case, the distribution of the proportion of PWOM/NWOM for all available products in the category would be necessary to classify the stated issue's potential limitations.

As these limitations could affect the study results, future research would improve the calculation and measurement methods, especially in PWOM and NWOM' virality' mentioned in 1.

Acknowledgement. This article is one of the partial outputs under the scientific research grant VEGA 1/0694/20 - Relational marketing research - perception of e-commerce aspects and its impact on purchasing behaviour and consumer preferences and VEGA 1/0609/19 - Research on the development of electronic and mobile commerce in the aspect of the impact of modern technologies and mobile communication platforms on consumer behaviour and consumer preferences. 


\section{References}

Askalidis, G., Kim, S. J., \& Malthouse, E. C. (2017). Understanding and overcoming biases in online review systems. Decision Support Systems, 97, 23-30. [Google Scholar] [CrossRef]

Badawi, Tjahjono, H. K., \& Muafi. (2017). The role of corporate reputation moderation of banking services. Polish Journal of Management Studies, 15(1), 15-25. [CrossRef]

Bakos, Y., \& Dellarocas, C. (2011). Cooperation without enforcement? A comparative analysis of litigation and online reputation as quality assurance mechanisms. Management Science, 57(11), 1944-1962. [Google Scholar] [CrossRef]

Balmer, J. M., \& Greyser, S. A. (2003). Revealing the corporation: perspectives on identity, image, reputation, corporate branding, and corporate-level marketing: an anthology. Psychology Press. [Google Scholar]

Basuroy, S., Chatterjee, S., \& Ravid, S. A. (2003). How critical are critical reviews? The box office effects of film critics, star power, and budgets. Journal of marketing, 67(4), 103-117. [Google Scholar] [CrossRef]

Berger, J., Sorensen, A. T., \& Rasmussen, S. J. (2010). Positive effects of negative publicity: When negative reviews increase sales. Marketing science, 29(5), 815-827. [Google Scholar] [CrossRef]

Bertan, S. (2020). Key Success Factors for Doing Business in Hot Air Balloon Riding. Journal of Tourism and Services, 11(20), 124-131. [Google Scholar] [CrossRef]

Bertarelli, S. (2015). On the efficacy of imperfect public-monitoring of seller reputation in e-commerce. Electronic Commerce Research and Applications, 14(2), 75-80. [Google Scholar] [CrossRef]

Bigosińska, K. (2015). Small and medium-size enterprises sector companies in disruptive innovation. In Forum Scientiae Oeconomia (Vol. 3, No. 3, pp. 13-20). [Google Scholar]

Bilan, S., Mishchuk, H., Samoliuk, N., \& Ostasz, G. (2020b). Effectiveness of social dialogue in the system of sustainable economic development factors. In Proceedings of the 34th International Business Information Management Association Conference, IBIMA (pp. 13303-13313).

Bilan, Y., Mishchuk, H., Samoliuk, N., \& Mishchuk, V. (2020a). Gender discrimination and its links with compensations and benefits practices in enterprises. Entrepreneurial Business and Economics Review, 8(3), 189-203. [Google Scholar] [CrossRef]

Book, L. A., Tanford, S., Montgomery, R., \& Love, C. (2018). Online traveler reviews as social influence: Price is no longer king. Journal of Hospitality \& Tourism Research, 42(3), 445-475. [Google Scholar] [CrossRef]

Brunner, C. B., Ullich, S., \& De Oliveira, M. J. (2019). The most optimal way to deal with negative consumer review: could positive brand and customer responses rebuild product purchase intentions?. Internet Research: Electronic Networking Applications and Policy, 29(1), 104-122. [Google Scholar] [CrossRef]

Cao, Q., Duan, W., \& Gan, Q. (2011). Exploring determinants of voting for the «helpfulness» of online user reviews: A text mining approach. Decision Support Systems, 50(2), 511-521. [Google Scholar] [CrossRef]

Chevalier, J. A., \& Mayzlin, D. (2006). The effect of word of mouth on sales: Online book reviews. Journal of marketing research, 43(3), 345-354. [Google Scholar] [CrossRef]

Chygryn, O., Bilan, Y., \& Kwilinski, A. (2020). Stakeholders of Green Competitiveness: Innovative Approaches for Creating Communicative System. Marketing and Management of Innovations, 3, 356-368. [CrossRef]

Cui, G., Lui, H. K., \& Guo, X. (2012). The effect of online consumer reviews on new product sales. International Journal of Electronic Commerce, 17(1), 39-58. [Google Scholar] [CrossRef]

De Matos, C. A., \& Rossi, C. A. V. (2008). Word-of-mouth communications in marketing: a meta-analytic review of the antecedents and moderators. Journal of the Academy of marketing science, 36(4), 578-596. [Google Scholar] [CrossRef]

DeMers, J. (2018). The 7 Biggest Social Media Fails of 2017. Retrieved from [Link]

Dzwigol, H. (2020). Innovation in Marketing Research: Quantitative and Qualitative Analysis. Marketing and Management of Innovations, 1, 128-135. [CrossRef]

East, R., Hammond, K., \& Wright, M. (2007). The relative incidence of positive and negative word of mouth: A multi-category study. International journal of research in marketing, 24(2), 175-184. [Google Scholar] [CrossRef]

East, R., Uncles, M. D., Romaniuk, J., \& Lomax, W. (2016). Measuring the impact of positive and negative word of mouth: A reappraisal. Australasian Marketing Journal (AMJ), 24(1), 54-58. [Google Scholar] [CrossRef]

Fedorko, R., \& Kakalejcik, L., (2015). Search Engine Optimization and its Importance in the Purchase Process. Proceedings of the Central european conference in finance and economics (CEFE 2015), 2015, Herlany, Slovakia, 155-163. Retrieved from [Link]

Ferencakova, L., Gajdka, K., Netek, V. \& Kapoun, P. (2020). Engaging Customers on Facebook Coffee Shops' Brand-Fan Pages. International Journal of Entrepreneurial Knowledge, 8(1), 65-75. [Google Scholar]

Forman, C., Ghose, A., \& Wiesenfeld, B. (2008). Examining the relationship between reviews and sales: The role of reviewer identity disclosure in electronic markets. Information systems research, 19(3), 291-313. [Google Scholar] [CrossRef]

Fortezza, F., \& Pencarelli, T. (2015). Potentialities of Web 2.0 and new challenges for destinations: insights from Italy. Anatolia, 26(4), 563-573. [Google Scholar] [CrossRef]

Girchenko, T. D., Panchenko, O.V. (2020). Research on the practical aspects of the providing efficiency of marketing communications' bank. Financial and credit activity-problems of theory and practice, 3. P. 13-22. [CrossRef] 
Godes, D., \& Mayzlin, D. (2004). Using online conversations to study word-of-mouth communication. Marketing science, 23(4), 545-560. [Google Scholar] [CrossRef]

Grebosz-Krawczyk, M. (2019). Attitudes of young consumers towards international nostalgic brands-the comparative study. Economics \& Sociology, 12(3), 181-191. [Google Scholar] [CrossRef]

Gretzel, U., \& Yoo, K. H. (2008). Use and impact of online travel reviews. Information and communication technologies in tourism 2008, 35-46. [Google Scholar] [CrossRef]

Hamari, J., Sjöklint, M., \& Ukkonen, A. (2016). The sharing economy: Why people participate in collaborative consumption. Journal of the association for information science and technology, 67(9), 2047-2059. [Google Scholar] [CrossRef]

Hennig-Thurau, T., Walsh, G., \& Walsh, G. (2003). Electronic word-of-mouth: Motives for and consequences of reading customer articulations on the Internet. International journal of electronic commerce, 8(2), 51-74. [Google Scholar] [CrossRef]

Keh, H. T., Chu, S., \& Xu, J. (2006). Efficiency, effectiveness and productivity of marketing in services. European Journal of Operational Research, 170(1), 265-276. [Google Scholar] [CrossRef]

Kim, R. B., \& Chao, Y. (2019). Effects of brand experience, brand image and brand trust on brand building process: The case of Chinese millennial generation consumers. Journal of International Studies, 12(3). [Google Scholar] [CrossRef]

Kim, S., \& Park, H. (2013). Effects of various characteristics of social commerce (s-commerce) on consumers' trust and trust performance. International Journal of Information Management, 33(2), 318-332. [Google Scholar] [CrossRef]

Kotler, P. Armstrong, G., \& Opresnik, M. O. (2017). Principles of Marketing (17e Global). Harlow: Pearson Education Limited.

Kumar, A., Bezawada, R., Rishika, R., Janakiraman, R., \& Kannan, P. K. (2016). From social to sale: The effects of firmgenerated content in social media on customer behavior. Journal of Marketing, 80(1), 7-25. [Google Scholar] [CrossRef]

Kuznyetsova A. Ya., Zherebylo I. V., Klipkova O. I., Kozmuk N. I. (2019). Creation of the value of national enterprises with the help of the innovation centers in the cluster formations. Financial and credit activities: problems of theory and practice 2(29), 391-402. [Google Scholar] [CrossRef]

Lackermair, G., Kailer, D., \& Kanmaz, K. (2013). Importance of online product reviews from a consumer's perspective. Advances in economics and business, 1(1), 1-5. [Google Scholar]

Leboff, G. (2011). Sticky marketing. Management Press, Prague, 2011.

Lee, J., Park, D. H., \& Han, I. (2008). The effect of negative online consumer reviews on product attitude: An information processing view. Electronic commerce research and applications, 7(3), 341-352. [Google Scholar] [CrossRef]

Lemon, K. N., \& Verhoef, P. C. (2016). Understanding customer experience throughout the customer journey. Journal of marketing, 80(6), 69-96. [Google Scholar] [CrossRef]

Li, X., \& Hitt, L. M. (2008). Self-selection and information role of online product reviews. Information Systems Research, 19(4), 456-474. [Google Scholar] [CrossRef]

Luca, M., \& Zervas, G. (2016). Fake it till you make it: Reputation, competition, and Yelp review fraud. Management Science, 62(12), 3412-3427. [Google Scholar] [CrossRef]

Malär, L., Krohmer, H., Hoyer, W. D., \& Nyffenegger, B. (2011). Emotional brand attachment and brand personality: The relative importance of the actual and the ideal self. Journal of marketing, 75(4), 35-52. [Google Scholar] [CrossRef]

Markovic, S., Iglesias, O., Singh, J. J., \& Sierra, V. (2018). How does the perceived ethicality of corporate services brands influence loyalty and positive word-of-mouth? Analyzing the roles of empathy, affective commitment, and perceived quality. Journal of Business Ethics, 148(4), 721-740. [Google Scholar] [CrossRef

Martin, W. C. (2017). Positive versus negative word-of-mouth: Effects on receivers. Academy of Marketing Studies Journal, 21(2), 1-10. [Google Scholar]

Mičík, M., \& Mičudová, K. (2018). Employer brand building: Using social media and career websites to attract generation Y. Economics \& Sociology, 11(3), 171-189. [Google Scholar] [CrossRef]

Miklosik, A., Starchon, P., Vokounova, D., \& Korcokova, M. (2020) The future of TV advertising targeting young Slovak consumers. Marketing and Management of Innovations, 2, 122-138. [Google Scholar] [CrossRef]

Mudambi, S. M., \& Schuff, D. (2010). What makes a helpful online review? a study of customer reviews on amazon. com. MIS Quarterly, 34(1), 185-200. [Google Scholar] [CrossRef]

Mura, L. (2020). Innovations And Marketing Management Of Family Businesses: Results Of Empirical Study. International Journal of Entrepreneurial Knowledge, 8(2), 56-66. [Google Scholar] [CrossRef]

Pencarelli, T., Škerháková, V., Ali Taha, V., \& Valentiny, T. (2018). Factors determining Italian online shoppers' preference of cash on delivery: empirical analysis. Polish Journal of Management Studies, 18. [Google Scholar] [CrossRef

Prayag, G., Hosany, S., Muskat, B., \& Del Chiappa, G. (2017). Understanding the relationships between tourists' emotional experiences, perceived overall image, satisfaction, and intention to recommend. Journal of Travel Research, 56(1), 41-54. [Google Scholar] [CrossRef

Proserpio, D., \& Zervas, G. (2017). Online reputation management: Estimating the impact of management responses on consumer reviews. Marketing Science, 36(5), 645-665. [Google Scholar] [CrossRef]

Robbins, M. (2018). Nearly 80 per cent of customers tell more people about a negative experience than a positive one. Retail World, 2017. Retrieved from [Link]

Romaniuk, J., \& Sharp, B. (2016). How brands grow. Part 2: Including emerging markets, services and durables, new brands and luxury brands. Oxford University Press. 
Schijns, J., \& van Bruggen, N. (2018). The Power of eWOM through Social Networking Sites. Journal of Marketing Development \& Competitiveness, 12(3). [Google Scholar]

Scott, D. M. (2015). The new rules of marketing and PR: How to use social media, online video, mobile applications, blogs, news releases, and viral marketing to reach buyers directly. John Wiley \& Sons. [Google Scholar]

Sernovitz, A. (2015). Word of Mouth Marketing: How Smart Companies Get People Talking. PressBox Publishing, Austin, 2015.

Shaw, C. (2018). 15 statistics that should change the business world - but haven't. 2013. Retrieved from [Link]

Siano, A., Vollero, A., \& Palazzo, M. (2011). Exploring the role of online consumer empowerment in reputation building: research questions and hypotheses. Journal of brand management, 19(1), 57-71. [Google Scholar] [CrossRef]

Smaiziene, I., \& Jucevicius, R. (2009). Corporate reputation: Multidisciplinary richness and search for a relevant definition. Engineering Economics, 62(2). [Google Scholar]

Stefko, R., Fedorko, R., \& Bacik, R. (2014). The Significance of Internet Marketing Tools in Terms of Building a Positive Image of an Higher Education Institution. Proceedings of the 24th International Business Information Management AssociationIBIMA 2014, Italy, 1772.

Sweeney, J., Soutar, G., \& Mazzarol, T. (2014). Factors enhancing word-of-mouth influence: positive and negative servicerelated messages. European Journal of Marketing, 48(1/2), 336-359. [Google Scholar] [Google Scholar]

Thakur, R. (2018). Customer engagement and online reviews. Journal of Retailing and Consumer Services, 41, 48-59. [Google Scholar] [CrossRef]

TripAdvisor Media Center. Retrieved from [Link]

Vaish, A., Grossmann, T., \& Woodward, A. (2008). Not all emotions are created equal: the negativity bias in social-emotional development. Psychological bulletin, 134(3), 383. [Google Scholar] [CrossRef]

Vázquez-Casielles, R., Suárez-Álvarez, L., \& del Río-Lanza, A. B. (2013). The word of mouth dynamic: How positive (and negative) WOM drives purchase probability: An analysis of interpersonal and non-interpersonal factors. Journal of Advertising Research, 53(1), 43-60. [Google Scholar] [CrossRef]

Victor, V., Nathan, R. J., Grabara, J., \& Fekete-Farkas, M. (2018). Price tracking behaviour in Electronic Commerce and the moderating role of fair price perception. Polish Journal of Management Studies, 18. [Google Scholar] [CrossRef]

Weberova, D., Starchon, P., Lizbetinova, L. (2016). Product Information and its Impact on Consumer Brand Perception. In: Proceedings of the 28th International Business-Information-Management-Association Conference, VISION 2020: Innovation management, development sustainability, and competitive economic growth, 1964-1974. [Google Scholar]

Wetzer, I. M., Zeelenberg, M., \& Pieters, R. (2007). «Never eat in that restaurant, I did!»: Exploring why people engage in negative word-of-mouth communication. Psychology \& Marketing, 24(8), 661-680. [Google Scholar] [CrossRef]

Yağmur, Y., \& Aksu, A. (2020). Destination Image of Antalya from the Perspectives of Tourists Staying in Hospitality Establishments with the Concept of Halal Tourism. Journal of Tourism and Services, 11(21), 103-128. [Google Scholar] [CrossRef]

Yin, D., Mitra, S., \& Zhang, H. (2016). Research note-When do consumers value positive vs. negative reviews? An empirical investigation of confirmation bias in online word of mouth. Information Systems Research, 27(1), 131-144. [Google Scholar] [CrossRef]

Лукас Какалейчик, Ph.D., GrowthPro s. r. o., Словаччина;

Річард Федорко, Ph.D., доцент, Пряшівський університет в Пряшеві, Словаччина;

Беата Гавурова, Ph.D., профресор, Технічний університет в Кошиие, Словаччина;

Радован Бачик, Ph.D., доцент, Пряшівський університет в Пряшеві, Словаччина.

Чи має маркетинг WoM негативний вплив на репутацію бренду?

У статті досліджується вплив негативних відгуків споживачів, які передаються через «сарафанне радіо» (WoM), на репутацію бренду/продукту. Авторами встановлено, що «сарафанне радіо» являє собою вербальний комунікаційний процес між споживачами щодо якості продукту. Систематизація літературних джерел з досліджуваної тематики засвідчила що поширення негативних відгуків може поставити під загрозу репутацію компанії та її існування. Таким чином, компанії змушені здійснювати значні фінансові вкладення для підтримки іміджу та залучення клієнтів. Це актуалізує питання аналізу суб'єктивних суджень споживачів щодо якості продуктів для уникнення поширення негативних відгуків. Метою роботи $є$ оцінка впливу поширення негативних відгуків серед споживачів на репутацію компанії/продукту. Вихідні дані для дослідження було сфрормовано на основі аналізу 100000 відгуків, згрупованих за шести категоріями. Об'єктом дослідження $€$ ринок Словаччини. У ході дослідження оцінено кількість позитивних та негативних відгуків, які передаються через сарафанне радіо. За результатами встановлено, що кількість позитивних відгуків у 15 разів перевищувала кількість негативних. На основі наявних наукових напрацювань, авторами запропоновано найкращий та найгірший сценарії можливого впливу негативних та позитивних відгуків на репутацію бренду компаній, що передаються через сарафанне радіо. Отримані результати дослідження свідчать про те, що пряме охоплення позитивними відгуками перевищує негативні. При цьому, в середньому, за найгіршого сценарію, пряме охоплення позитивними відгуками перевищує негативні в 3,93 раза, тоді як за найкращого сценарію - у 8,85 раза. Таким чином, встановлено, що поширення позитивних відгуків має сильніший вплив на збереження репутації бренду. Запропоновано менеджерам компаній рекомендовано 
L., Kakalejcik, R., Fedorko, B., Gavurova, R., Bacik. Can Negative Word-of-Mouth Have Any Impact on Brand Sustainability?

залучати більше амбасадорів, задоволених брендом, для уникнення потенційної небезпеки щодо поширення негативу серед незадоволених споживачів.

Ключові слова: ефект сарафранного радіо, сприйняття бренду, управління брендом, репутація бренду. 